\title{
WHAT DRIVES PEASANT HOUSEHOLD TO COMMERCIALIZE? AN INVESTIGATION OF THE FACTORS LEADING TO COMMERCIALIZATION OF SEMI-SUBSISTENCE FARMING IN UKRAINE
}

\author{
Inna Koblianska ${ }^{1}$, Oleh Pasko², Tetiana Marenych ${ }^{3}$, \\ Nataliia Kotseruba ${ }^{4}$, Viktoriia Tkachenko ${ }^{5}$ \\ *Corresponding author E-mail: koblianska@protonmail.com
}

ART I C LE IN F O

Original Article

Received: 27 October 2020

Accepted: 20 November 2020

doi:10.5937/ekoPolj2004169K

UDC 338.43:[64:711.3(477)

Keywords:

households, semi-subsistence farming, commercialisation, self-sufficiency, policy

JEL: $013, R 38, Q 18$

\begin{abstract}
A B S T R A C T
More than half of the total number of households in Ukraine are engaged in agricultural activities both for food self-sufficiency and for the production of marketable agricultural products, acting as subsistence or semisubsistence farms. The determination of the right strategy for the further development of this form of farming is the key to the effective development of the agricultural sector, rural areas and the national economy as a whole. Instigated by Europe's CAP policy and its implementation, the study seeks to and delivers the factors influencing the commercialization of the semi-subsistence farms in Ukraine, based on the wealth of statistical data. The findings also show the lack of a strategy to support the establishment of a model of individual farming, which must counteract the risks of industrialized agro-production.
\end{abstract}

(C) 2020 EA. All rights reserved.

1 Inna Koblianska, PhD, Associate Professor, Faculty of Economics and Management, Sumy National Agrarian University, H.Kondratiev str., 160, 40021, Sumy, Ukraine. Phone: +380501966431. E-mail: koblianska@protonmail.com, ORCID ID (http://orcid.org/0000-0002-7844-9786)

2 Oleh Pasko, PhD, Associate Professor, Faculty of Economics and Management, Sumy National Agrarian University, H.Kondratiev str., 160, 40021, Sumy, Ukraine. Phone: +380503073138. E-mail: oleh.pasko@snau.edu.ua, ORCID ID (http://orcid.org/0000-0002-6275-5885)

3 Tetiana Marenych, Doctor of science, Professor, Head of the Department of Accounting and Audit, Educational and Scientific Institute of Business and Management, Kharkiv Petro Vasylenko National Technical University of Agriculture, Alchevskikh str., 44, 61002, Kharkiv, Ukraine, Phone: +380661036811. E-mail: oblikua7@gmail.com, ORCID ID (http://orcid.org/0000-0002-8502-1884)

4 Nataliia Kotseruba, PhD, Associate Professor, Faculty of Accounting and Finance, Vinnytsia Institute of Trade and Economics of Kyiv National University of Trade and Economics, Soborna str., 87, 21050, Vinnytsia, Ukraine, Phone: +380983185267. E-mail: kotseruba@ vtei.com.ua, ORCID ID (http://orcid.org/0000-0001-5161-318X)

5 Viktoriia Tkachenko, PhD, Associate Professor, Faculty of Economics and Management, Sumy National Agrarian University, H.Kondratiev str., 160, 40021, Sumy, Ukraine. Phone: +380994377427. E-mail: viktoriia.tkachenko@snau.edu.ua, ORCID ID (https://orcid. org/0000-0002-2924-4012)

http://ea.bg.ac.rs 


\section{Introduction}

As of early 2019, there were 8,175.8 thousand households in Ukraine that are in one way or another related to agricultural production (identified legally as households plots (hereinafter referred to as HP or households)). To illustrate the scale (prevalence) of this phenomenon, it should be noted that it is more than half $(55 \%)$ of the total number of households in the country. Aggregate households that include, according to the methodology of the State Statistics Service of Ukraine, households engaged in agricultural activities both for food self-sufficiency and for the production of marketable agricultural products (households in rural areas, households in urban areas, as well as physical persons - entrepreneurs who conduct their activities in the field of agriculture without creating a legal entity) in 2018 produced $41.24 \%$ of agricultural production in Ukraine (for comparison - farmers - just over 7\%) (SSSU 2015). Furthermore, households are indeed the main producer of such food as potatoes, vegetable and melon crops (92\%), fruit, berry and grapes (79.74\%), livestock products, including milk (73.14\%), wool (87.5\%) and other livestock products, including honey (98\% according to 2017$)$. Households account for more than a third of total meat production $(36.14 \%)$ and a significant proportion of egg production $(44.83 \%$ ) (AGRICULTURE OF UKRAINE, 2018; SSSU; SSSU 2018). This determines their crucial role in providing the population with food and guaranteeing country's food security.

However, for the most part, households are production units with low land-use efficiency. According to 2018 data, the average yield in households is, for the most part, lower than in the enterprises, with the exception being the production of grapes and fruits and berries. Households are characterized by a low level of technological development of production (for example, on average, only $9.8 \%$ of producers use breeding stock, artificial insemination - 13.8\%). Another problem is the lack of assurance of product safety (for example, only $17.9 \%$ of producers use milk sanitary quality control and a little more than half - 57.7\% resort to the sanitary treatment of livestock premises) (AGRICULTURE OF UKRAINE, 2018; SSSU; SSSU 2018). Moreover, without the status of entrepreneurial units, such organizational forms of business do not contribute much to the development of the local economy (due to the lack of income tax obligations and voluntary social insurance (LAW OF UKRAINE 2003). Therefore, low efficiency and technological level, a small contribution to the development of the local economy are the hallmarks of such a large category of producers as "households" in Ukraine.

On the other hand, the role of these farms is significant in terms of the social development of rural areas (Popescu, 2014). Keeping traditional methods of production and culture, households also act as employers, as an average of $2.3 \%$ of them attract permanent employees, for seasonal work - 52.3\%, and for one-time work - 45.4\%. However, it should be emphasized that this employment is informal and generally run counter to the requirements of the law. Here we should emphasize the need to clearly distinguish between households plots (HP) and Personal peasant household (hereinafter referred to as PPH), although, and it is very important, the latter are included into the former. Persons whose main activities are carried out within the framework of Personal 
peasant household under the Law of the same name (LAW OF UKRAINE 2003) (which is $48.9 \%$ of the total number of "households") are recognized as self-sufficient and are self-employed persons. Thus, PPHs emerge as the "primary" form (a form of first preference) of organization of business activity in the countryside (although the Law does not recognize this), and the massive stratum of people involved in the production processes of PPHs forms the potential for rural business development. We also emphasize that the socio-economic role of households, in particular in rural areas, is that they help urban relatives in terms of income and food.

At the same time, following the typology proposed in (Davidova, 2014), the class of small food producers in Ukraine - the "household" - formed in Ukraine leads to a subsistence form of farming. This is confirmed by the fact that in 2018, on average, $20.7 \%$ of urban land is used for growing produce for own use only, while only $1.3 \%$ for own use and sale. In rural areas, on average, $15.7 \%$ of the land area of the farm is devoted to growing produce for own use only, while on average $10.0 \%$ is allocated for own use and sale. We utilize the data on the distribution of land area due to the paucity of reliable statistical estimates of the volume and share of products sold by farms on the market.

The risks of the spread of subsistence farming in terms of food security, social efficiency of rural production and development have been extensively explored in the works of EU researchers (Buchenrieder, 2009; Fritzsch, 2010; Davidova, 2011; Forgács, 2012; Alexandri, Luca and Kevorchian, 2015; Jędrzejczak-Gas, 2018) and illustrated by us above in the national context: low resource use efficiency, low technology and product safety, low contribution to community development, informal employment, etc.

Thus, in the conditions of globalization of the world agricultural market, digitization of all spheres of public life, strengthening of market relations in various sectors of the Ukrainian economy, including agrarian in the conditions of world competition, such a phenomenon as a semi-subsistence economy cannot continue to exist on such scales. Determining the right strategy for the further development of this form of business is the key to the effective development of the agricultural sector, rural areas and the national economy as a whole. Moreover, it is not only a matter of economic policy but of public policy in general, as the focus is on the well-being, safety and quality of life of more than 20 million Ukrainians.

Moreover, the EU has similar to Ukraine situation where about 70 per cent of EU holdings have an area of fewer than 5 hectares and around half are defined as semisubsistent (Davidova, 2014). We emphasize that this idea defines, to a large extent, the current format of the EU's Common agricultural policy - CAP, where the problem of the spread of the semi-subsistence farms has been exacerbated with the Eastern European enlargement of the EU borders and the accession of new members. Today, the need to look for mechanisms to transform this form of business into market-adapted is recognized as one of the important tasks of the CAP and EU rural development policy (SECTION 1 Axis 1, Article 20 (i) Council Regulation (EC) No 1698/2005 of 20 September 2005). 
Another important question is to see the perspective clearly and to act according to it employing all governance mechanisms available. The FAO, for example, estimates that global agricultural output will need to rise by at least 70 per cent by 2050 (FAO, 2009) and given the efficiency gap between large-scale and family farms the balance inevitable will be shifting towards former. The CAP's direct payments slow this shift, but "cannot, in the long run, prevent the structure of EU agriculture evolving to an industry where the overwhelming bulk of production is generated by larger- scale, capital intensive farms" (Rickard, 2015, p. 51)

For Ukraine, the urgency and importance of overcoming this problem also lie in the fact that restructuring of farming should be seen as an important component of market transformation and a necessary condition for the success of land reform aimed at the effective use of all productive means by market-oriented users (Lerman, Csaki and Feder, 2002).

The paper contributes to the literature in several ways. The study introduces into the English language scholarly literature Ukraine's case of semi-subsistence farming (hereinafter referred to as SSF), covering the decade long period (2008-2018) of its evolution in Ukraine. Doing so, the paper put on the map of SSF literature the biggest (in terms of area) country in Europe rich on the fertile ground (black soil). Instigated by Europe's CAP policy and its implementation, the study seeks to and delivers, based on the wealth of statistical data, to identify the factors that have a positive impact on the commercialization of the SSF in Ukraine. The findings of the paper due to similar institutional and cultural settings are applicable to the host of other countries sharing common past with Ukraine.

This paper proceeds by presenting the literature review in Section 2. After that, Section 3 presents the research methods, followed by the presentation of the main findings in Section 4. Finally, Section 5 brings the conclusions, highlighting the main findings as well as theoretical and practical implications, and venues for future research.

\section{Literature review}

As mentioned above, the need to overcome the problem of subsistence and the spread of subsistence farming, in particular through the introduction of measures to commercialize such farms, is one of the objectives of the CAP and EU rural development policy (SECTION 1 Axis 1, Article 20 (i) Council Regulation (EC) No 1698/2005 of 20 September 2005). At the same time, other potential directions for transforming farms are offered: by integrating them into larger-scale companies or by maintaining the existing status quo (mainly through the social, cultural and environmental function of farms) (Davidova, 2011). Some tools within the outlined areas have also been introduced in the EU CAP (EUROPEAN PARLIAMENT 2013), but it is obvious from the results of the CAP implementation that this is not a one-size-fits-all situation (EUROPEAN PARLIAMENT 2013). An effective policy aimed at overcoming the SSF path dependence should study the rationale, reasons and motives that determine the involvement of the people in conducting this form of farms. 
The causes of the emergence and spread of such a phenomenon as semi-subsistence farming have not yet been fully established (Buchenrieder, 2009). Some studies (Fredriksson et al., 2016) indicate that the need for subsistence farming increases as the economic burden on its members' increases, while alternative (off-farm) income reduces the need for subsistence consumption and increases the volume of products consumed/sold in the market (Fredriksson et al., 2016; Csata, 2018), and therefore is a factor of the commercialization of farm operations. Davidova notes that the SSF is a consequence of market imperfection, but market-oriented subsistence farms and subsistence-oriented farmers can be distinguished. The former are highly motivated to produce to the market, while the leftovers are consumed, they are more responsive to market and political signals (Davidova, 2011, p. 505).

Equally important is the role of socio-cultural factors. The mentality is one of the reasons for maintaining the SSF in Moldova (WORLD BANK 2016). In this case, the prevailing distrust of the population in the formal institutions and the need to create a 'cushion' against poverty in an inadequate state welfare system determine the dominance of the SSF in Moldova (WORLD BANK 2016, p. 27). From this stems low activity in the land market, while the land is considered as a stock and a source of constant income (WORLD BANK 2016). Summarizing the findings of research by scholars on this problem in Hungary, Moldova, Romania (Giurca, 2008; Fritzsch, 2010; Forgács, 2012; Alexandri, Luca and Kevorchian, 2015), we emphasize that the common problem is the moral and ethical basis running a semi-subsistence farm in a semi-legal form, which consists in efforts to avoid taxation and exploit the opportunities available to them while avoiding responsibility for community development, paternalistic attitudes (Strochenko, 2016).

Among the reasons for the spread of the SSF in the Eastern European area can be distinguished historical and cultural, due to the dominance of the socialist system. In this case, the imperfection of the relations (incompleteness of transformational accomplishments) regarding the disposal of the land, which was transferred to private hands, raises the problem of SSF. In particular, Lerman, Csaki and Feder point out that the rationing and privatization of land must go hand in hand with ensuring the free movement of rights to these land (sale, lease), emphasizing that this is a prerequisite for effective land relations reforms in post-socialist countries (Lerman, Csaki and Feder, 2002). At the same time, not all countries implemented these transformations on time (Lerman, 2012), including Ukraine.

After all, the above mentioned are factors of an external nature, formed by general historical, cultural, organizational, political, and socio-economic conditions. At the same time, several internal factors determine a person's (landowner's) predisposition to forms of land use. These factors include, but are not limited to, age, level of education, psychological characteristics, etc. Depending on these factors, Buchenrieder et al. (2009) identified in their work the types of SSF owners such as 1) Rural pensioners, 2) Farmers, 3) Rural diversifiers and 4) Rural newcomers, modelling different policy strategies aimed at improving economic efficiency for each type of SSF. Combining http://ea.bg.ac.rs 
external factors and internal characteristics of household owners, Davidova (2011) identifies the following types of farmers: (i) farmers pushed to subsistence by market imperfections and an underdeveloped social safety net for whom semi-subsistence is a coping strategy; (ii) part-time farmers with other gainful activities; (iii) semi-subsistence farmers by choice, sometimes known as hobby or lifestyle farmers (Davidova, 2011, p. 505). Despite the differences in those approaches, researchers are united that SSF is a heterogeneous group of farm owners with different motivation and degree of aptitude for agriculture, which determines the difficulty of finding effective and efficient measures of political regulation (Buchenrieder, 2009; Davidova, 2014).

Given the scale of the spread of subsistence farming in Ukraine, the risks of neglecting this problem in the area of policy decisions on agriculture and rural development, and the paucity of research related to it (although some aspects of this problem are explored in Strochenko, 2016; Strochenko, 2017; socio-economic and legal problems of PPH functioning were investigated in the works of Svynous (2009), there is an objective need to study the factors that influence the propagation and preservation of semisubsistence farming as well as the identification of the factors that have a positive impact on the commercialization of the activities of households as the main producer of end-use agricultural products in the country. All those defines the main purpose of this study and, in our view, should lay the groundwork for formulating effective policies aimed at the organizational transformation in agricultural production and rural economy under the current conditions: European integration, expansion of Ukraine in the world agri-food market, market reforms and others. It is our understanding that the results of the paper due to shared institutional settings are applicable to the numerous other jurisdictions who are on the same footing with Ukraine.

\section{Materials and methods}

Our method is analytical logic based on official statistics underpinned by the correlation analysis. Official statistics provided by the State Statistics Service of Ukraine were used in the paper. Applying the correlation analysis, the relationship between the trends and the main characteristics of agricultural activity of households in regions as well as socio-economic conditions of regions development is investigated. Based on a comparison of changes in the basic parameters characterizing the agricultural activity of farms over time, structural changes in the private sector of the agricultural sector of the country are established.

\section{Results and discussions}

Semi subsistence framing requires a certain resource base - land in ownership or use. Available land has both urban (3376.0 thousand in 2018) and rural (4799.8 thousand in 2018) households in Ukraine. Of course, owning land does not necessarily mean cultivating it directly by the owner, and therefore, unlike to the case of livestock, poultry and bees households, it does not mean becoming a household model of subsistence farming. However, the availability of land is a prerequisite for the formation of a 
layer of SSF. So, let's examine the socio-economic factors that have an impact on the dynamics of the number of landowners in the regional context and the way they use their land (Table 1).

Table 1. Results of the correlation analysis of the relationship between the spread of subsistence farming in regions with socio-economic conditions for regional development, 2018

\begin{tabular}{|c|c|c|c|c|c|}
\hline Indicator & 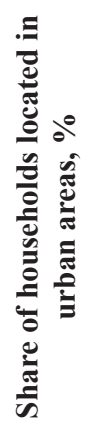 & 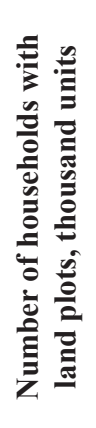 & 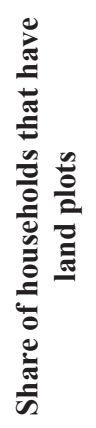 & 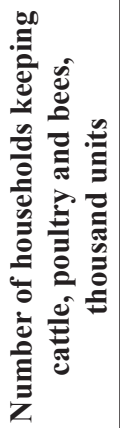 & 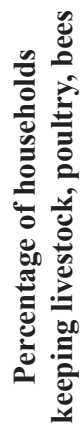 \\
\hline Number of households, total, thousand units & 0,73 & 0,89 & $-0,81$ & 0,10 & $-0,79$ \\
\hline $\begin{array}{l}\text { Number of households located in urban settlements, } \\
\text { thousand units }\end{array}$ & 0,83 & 0,82 & $-0,84$ & $-0,09$ & $-0,84$ \\
\hline Share of households located in urban areas, $\%$ & 1,0 & 0,51 & $-0,80$ & $-0,42$ & $-0,90$ \\
\hline $\begin{array}{l}\text { Number of households located in rural settlements, } \\
\text { thousand units }\end{array}$ & $-0,28$ & 0,56 & $-0,10$ & 0,85 & 0,06 \\
\hline Average household size, persons & $-0,65$ & $-0,32$ & 0,33 & 0,24 & 0,55 \\
\hline $\begin{array}{l}\text { Number of households without a single worker, } \\
\text { thousand units }\end{array}$ & 0,77 & 0,86 & $-0,74$ & 0,00 & $-0,79$ \\
\hline Percentage of households with workers, $\%$ & 0,22 & $-0,07$ & 0,11 & $-0,25$ & $-0,08$ \\
\hline Average number of employees per farm, persons & $-0,38$ & $-0,02$ & 0,05 & 0,30 & 0,24 \\
\hline The coefficient of economic load per worker, times & $-0,22$ & $-0,35$ & 0,32 & $-0,15$ & 0,31 \\
\hline $\begin{array}{l}\text { The level of economic activity at the age of } 15-70 \\
\text { years, } \%\end{array}$ & 0,29 & 0,04 & $-0,12$ & $-0,09$ & $-0,21$ \\
\hline $\begin{array}{l}\text { Unemployment rate as a percentage of economically } \\
\text { active population of } 15-70 \text { years, } \%\end{array}$ & 0,05 & $-0,37$ & 0,29 & $-0,37$ & 0,18 \\
\hline $\begin{array}{l}\text { Percentage of informally employed population as \% } \\
\text { to employed population, } \%\end{array}$ & $-0,54$ & $-0,56$ & 0,50 & $-0,01$ & 0,59 \\
\hline $\begin{array}{l}\text { The average area of land (in hundredth parts of a } \\
\text { hectare) used by the farm }\end{array}$ & 0,54 & $-0,17$ & $-0,32$ & $-0,62$ & $-0,47$ \\
\hline \multicolumn{6}{|c|}{ Distribution of land area by the direction of its use, $\%$} \\
\hline for the grow of produce only for their own needs & $-0,48$ & $-0,07$ & 0,23 & 0,47 & 0,47 \\
\hline for the grow of produce for own needs and for sale & $-0,48$ & $-0,66$ & 0,45 & $-0,25$ & 0,50 \\
\hline leased out & 0,60 & 0,29 & $-0,37$ & $-0,33$ & $-0,60$ \\
\hline for leisure only & 0,00 & 0,01 & $-0,07$ & 0,16 & 0,09 \\
\hline just started to master & $-0,42$ & $-0,38$ & 0,46 & 0,08 & 0,55 \\
\hline $\begin{array}{l}\text { The number of Personal peasant households (PPH), } \\
\text { thousand units }\end{array}$ & $-0,59$ & 0,29 & 0,22 & 0,84 & 0,39 \\
\hline $\begin{array}{l}\text { The area of land used by PPH, thousand hectares, } \\
\text { including: }\end{array}$ & 0,28 & 0,29 & $-0,56$ & 0,08 & $-0,39$ \\
\hline
\end{tabular}




\begin{tabular}{|c|c|c|c|c|c|}
\hline Indicator & 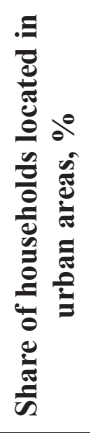 & 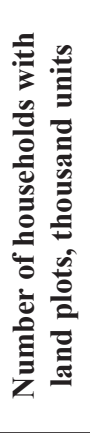 & 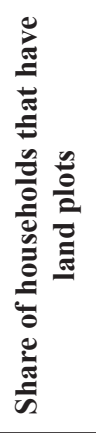 & 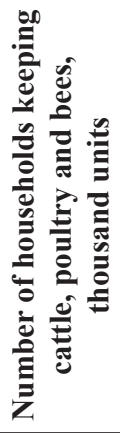 & 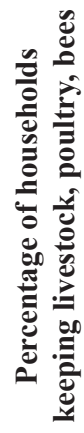 \\
\hline $\begin{array}{l}\text { for the construction and maintenance of a } \\
\text { dwelling house, outbuildings and structures }\end{array}$ & $-0,54$ & 0,32 & 0,19 & 0,79 & 0,35 \\
\hline - $\quad$ for the conduct of personal peasant households & $-0,39$ & 0,00 & 0,10 & 0,53 & 0,35 \\
\hline $\begin{array}{l}\text { - for conducting commodity agricultural } \\
\text { production }\end{array}$ & 0,61 & 0,26 & $-0,68$ & $-0,33$ & $-0,66$ \\
\hline - of which were rented & 0,74 & 0,31 & $-0,70$ & $-0,46$ & $-0,75$ \\
\hline
\end{tabular}

Source: calculated by data (SSSU) and data from http://www.ukrstat.gov.ua/

As an introduction to your analysis, we would like to note that, by examining both absolute and relative indicators of land use, we try to: 1) find out whether there is a relationship between the socio-economic conditions of the region's development and the dynamics of the number of households with land and households engaged in animal husbandry; 2) to find out whether there is a link between the socio-economic conditions of the region's development and the prevalence (proxy: the share in the total number of households in the region) of households with land and households engaged in animal husbandry.

Our analysis based on the calculation of the correlation coefficients, allows us to draw the following conclusions:

1. There is a close and positive relationship between the number of households in the region and the number of households with land (0.89). Close but inverse relationship exists between the number of households and the share of those who have land $(-0.81)$. From this, we can conclude that in regions with more households (more densely populated) such phenomenon as land ownership will be less common. The same applies to households keeping cattle, poultry and bees (-0.79);

2. The relationship between the level of urbanization (share of households in urban settlements) and the number of households having land plots is positive, albeit of medium intensity, but given the degree and nature of the relationship between urbanization level and land ownership (-0.8) it can be inferred that with increasing urbanization in the region there is a decrease in the prevalence of such phenomenon as land ownership. The same is true for the number of livestock households $(-0.42)$ and the prevalence of this phenomenon (-0.9);

3. The land ownership is characteristic of both rural and urban areas. At the same time, the phenomenon of cattle, poultry and beekeeping is characteristic of regions 
with lower levels of urbanization $(-0.42)$. With the increase in the number of rural households in the region leads to a growing number of livestock holding households (0.85).

4. With the increase in the average household size in the region, there is a decrease in the number of households with land (-0.32), but an increase in the prevalence of this phenomenon (0.33). Commenting on these results, it should be noted that larger average household size is typical for rural areas. This, to some extent, explains together with the above comments such results, and should also be taken into account when assessing the degree and nature of the relationship between the average size of the households and the number and prevalence of such a phenomenon as household keeping livestock, poultry and bees $(0,24$ and 0.55 , respectively).

5. In regions with a difficult socio-economic situation (higher proportion of households without workers, a higher ratio of economic burden per worker), land tenure is more common ( 0.11 and 0.32 , respectively). At the same time, the proportion of households with no workers is reversely related, although not significantly to the number of livestock households and the prevalence of this phenomenon $(-0.25$ and -0.08 , respectively). With increasing labour availability (the average number of employees per farm) grows also the number of livestock households $(0.3)$ and the prevalence of this phenomenon (0.24). It should be emphasized that the proportion of households without workers, although not insignificant, is related to the level of urbanization (0.22). Therefore, that corroborates our findings regarding the link between workforce availability and livestock farming and is not predicated on the overall difficult situation in rural Ukraine.

6. The economic burden is higher in rural areas, and this explains the positive (although insignificant) link of this indicator and the prevalence of land ownership and animal keeping (0.32 and 0.31, respectively), although, in our opinion, this does not preclude some interdependence of those phenomena.

7. It is worth noting that the number, as well as the prevalence of land ownership as well as keeping animals by households, is only insignificantly correlated with levels of economic activity and unemployment. Unemployment is a "universal phenomenon" (in terms of universality for rural and urban areas) and even more positively related to the level of urbanization (albeit not significantly - 0.05). Therefore, as it (the unemployment rate) rises in the region, the number of households with the land is decreasing, although the prevalence of this phenomenon is increasing ( -0.37 and 0.29 , respectively). At the same time, the number of households keeping livestock, poultry and bees is also decreasing $(-0.37)$.

8. Informal employment is positively, although indirectly related to the proportion of rural households (0.54), this can explain the significance of the correlation coefficients between the share of the informally employed population and the prevalence of land tenure and households that keep animals (since these phenomena are common in rural areas) -0.5 and 0.59 , respectively. 
9. As the level of urbanization increases, the average land area of a household grows (0.54), with most of it being used for renting (0.6), while decreasing the proportion allocated for growing produce for own use only $(-0.48)$, for own use and sale $(-0.48)$.

10.The larger the share of households that have land, the greater the proportion of space allocated for growing produce for their own use and sale $(0.45)$. The same is true for the prevalence of livestock farming in households $(0.5)$.

11. The value of the correlation coefficient between the allocation of the share of land used only for the cultivation of produce for own use and the number and prevalence of livestock households (0.47 and 0.47$)$ indicates that such farms are predominantly used the land for self-sufficiency purpose, both in rural and urban settlements.

12. With increasing urbanization, the number of households is decreasing $(-0.59)$, although such farms are larger, as there is a positive (albeit mediocre 0.29) relationship between the size of the total land area of the HP in the region. In the more urbanized territories, larger areas of HPs allocate most of the area for agricultural commodity production (0.61), actively using leased land (0.74).

13.The more widespread in the region is land ownership and livestock farming (regions with less urbanization), the smaller the share of land used in commodity production (-0.68 and -0.66). However, this is not generally the case for livestock farms. They mainly use the land area to maintain a house and a household. However, for rural areas (where livestock farms are more prevalent), this relationship is mediocre (0.35 and 0.35), whereas in general, and thus more closely for urban areas, its closeness is increasing ( 0.79 and 0,53 , respectively). Obviously, with the increase in both the number and the prevalence of livestock farms, allotment of land for commodity production is shrinking, which suggests that such farms are predominantly geared to meeting their own food needs.

Considering that the availability of land is not directly related to subsistence farming, let us analyze the features (causes and extent) of subsistence farming in urban and rural settlements. However, we will first of all comment on the general trends in the dynamics of indicators on the functioning of farms in rural and urban settlements (Table 2).

Table 2. Profile of households' plots in rural and urban settlements, 2008, 2018

\begin{tabular}{|l|c|c|c|c|}
\hline \multirow{2}{*}{\multicolumn{1}{|c|}{ Indicator }} & \multicolumn{2}{c|}{$\begin{array}{c}\text { Located in rural } \\
\text { settlements }\end{array}$} & \multicolumn{2}{c|}{ Located in urban areas } \\
\cline { 2 - 5 } & $\mathbf{2 0 0 8}$ & $\mathbf{2 0 1 8}$ & $\mathbf{2 0 0 8}$ & $\mathbf{2 0 1 8}$ \\
\hline Number of households, thousand & 5334,2 & 4873,6 & 11864,8 & 10061,3 \\
\hline Average size, persons & 2,74 & 2,67 & 2,54 & 2,54 \\
\hline Percentage of households without workers & 50,2 & 44,2 & 28,9 & 31,2 \\
\hline $\begin{array}{l}\text { Average number of employees per household, } \\
\text { persons }\end{array}$ & 0,8 & 0,9 & 1,2 & 1,1 \\
\hline $\begin{array}{l}\text { The coefficient of economic load on a working } \\
\text { member of the farm, times }\end{array}$ & 3,41 & 3,01 & 2,09 & 2,30 \\
\hline
\end{tabular}




\begin{tabular}{|l|c|c|c|c|}
\hline \multirow{2}{*}{ Indicator } & \multicolumn{2}{c|}{$\begin{array}{c}\text { Located in rural } \\
\text { settlements }\end{array}$} & \multicolumn{2}{c|}{ Located in urban areas } \\
\cline { 2 - 5 } & $\mathbf{2 0 0 8}$ & $\mathbf{2 0 1 8}$ & $\mathbf{2 0 0 8}$ & $\mathbf{2 0 1 8}$ \\
\hline Share of expenditure on food in expenses, \% & 55,4 & 44,60 & 49,6 & 49,80 \\
\hline $\begin{array}{l}\text { Share of remuneration and income from } \\
\text { entrepreneurship and self-employment in } \\
\text { aggregate resources, \% }\end{array}$ & 36,4 & 47,00 & 61,4 & 67,30 \\
\hline $\begin{array}{l}\text { Personal peasant households having land plots, } \\
\text { thousand }\end{array}$ & 5262,6 & 4799,8 & 4454,7 & 3376,0 \\
\hline Share of households with land, \% & 98,66 & 98,49 & 37,55 & 33,55 \\
\hline $\begin{array}{l}\text { The average size of the land, in hundredth parts } \\
\text { of a hectare }\end{array}$ & 314,3 & 292,1 & 21,1 & 46,9 \\
\hline $\begin{array}{l}\text { Share of households keeping cattle, poultry and } \\
\text { bees, \% }\end{array}$ & 80,9 & 76,0 & 9,2 & 8,1 \\
\hline \multicolumn{1}{|c|}{ Distribution of land area by type of household use (among households having land and using it by } \\
direction), \%
\end{tabular}

Source: calculated by data (SSSU) and data from http://www.ukrstat.gov.ua/

Therefore, as the data show, there is a reduction in the number of households in general as well as of HP in rural and urban areas. Particularly notable is the decrease in the proportion of the latter in urban settlements (by $4.0 \%$ ). In this case, the average size of the land plot in a rural area decreases (by 22.2 hundredth parts of a hectare), but almost twice the average size of a plot of an urban household increases. The share of households keeping livestock, poultry and bees in rural and urban settlements is reduced; rural households are becoming more oriented on semi-subsistence (by the proportion of land allocated for cultivation for their own needs), reducing the proportion of land used for the commercial aim. The same is true for urban households, which, besides, have significantly (more than 2 times) reduced the proportion of land reserved for their own food needs. Distinctive for rural and urban households is the tendency to lease out the land. This, in turn, is one way of overcoming the naturalization of economic activity (EU Policy Review).

Therefore, considering the significant differences in the directions of land use in urban and rural settlements, as well as the difference in socio-economic conditions of urban and rural territories development, let us examine what factors influence the transformation of semi-subsistence households in urban areas (Table 3).

The number of subsistence farms in urban settlements (those with land plots) correlates closely and positively with the number of urban households in general (0.97). At the same time, the dynamics of the prevalence of this phenomenon is not closely related 
to the dynamics of the number of households. Indeed, over time, the proportion of subsistence farms in urban settlements has decreased: $33.55 \%$ in 2018 versus $37.55 \%$ in 2018 (Table 2).

What are the factors that matter here? The reduction in the number and proportion of households with the land is closely correlated with the increase in the proportion of households without any single worker (-0.71). In 2008, there were $28.9 \%$ of such households and in $2018-31.2 \%$. So, contrary to popular belief, that households are chiefly for retirees - in fact, this is not the case. Also, the reduction in the average number of workers per farm (from 1.2 in 2008 to 1.1 in 2018) correlates closely and positively with the reduction in the share of households (0.82) and slightly less closely with their number (0.57). An increase in the economic load ratio per working member of the household is closely linked to a decrease in the number $(-0.92)$ and the prevalence $(-0.87)$ of households' plots.

Table 3. Results of the correlation analysis of the relation between the characteristics of HPs in urban settlements with socio-economic conditions of urban settlements development, 20082018

\begin{tabular}{|c|c|c|c|c|c|c|c|c|c|c|c|}
\hline Indicator & 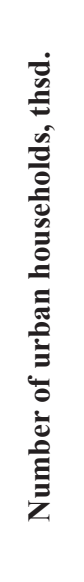 & 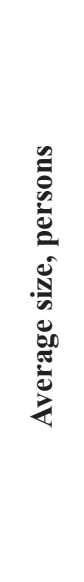 & 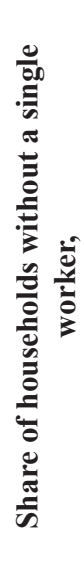 & 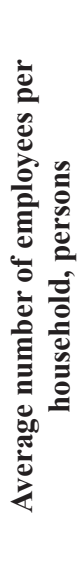 & 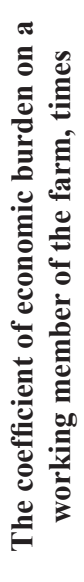 & 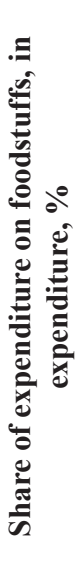 & 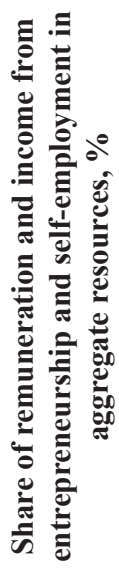 & 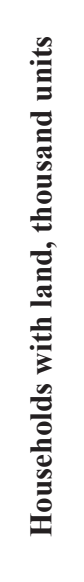 & 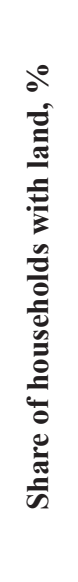 & 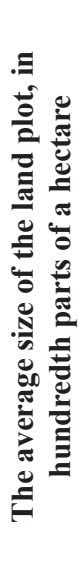 & 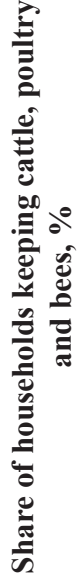 \\
\hline $\begin{array}{l}\text { PPH having } \\
\text { land plots, } \\
\text { thousand }\end{array}$ & 0,97 & $-0,37$ & $-0,71$ & 0,57 & $-0,92$ & 0,08 & $-0,51$ & 1,00 & 0,89 & $-0,74$ & 0,21 \\
\hline $\begin{array}{l}\text { Share of } \\
\text { households } \\
\text { with land in the } \\
\text { total number } \\
\text { of urban } \\
\text { households, \% }\end{array}$ & 0,75 & 0,02 & $-0,71$ & 0,82 & $-0,87$ & $-0,11$ & $-0,58$ & 0,89 & 1,00 & $-0,76$ & 0,44 \\
\hline $\begin{array}{l}\text { The average } \\
\text { size of the } \\
\text { land plot, in } \\
\text { hundredth parts } \\
\text { of a hectare }\end{array}$ & $-0,66$ & 0,16 & 0,69 & $-0,81$ & 0,89 & 0,20 & 0,31 & $-0,74$ & $-0,76$ & 1,00 & $-0,03$ \\
\hline
\end{tabular}




\begin{tabular}{|c|c|c|c|c|c|c|c|c|c|c|c|}
\hline Indicator & 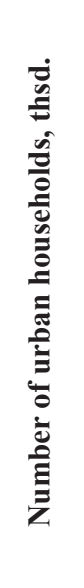 & 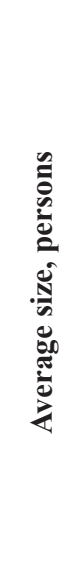 & 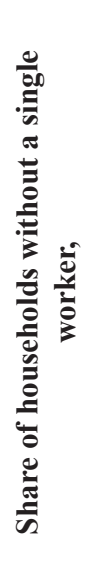 & 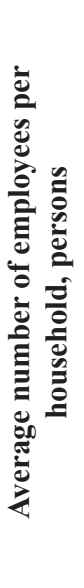 & 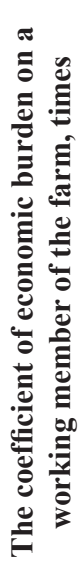 & 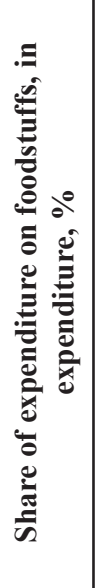 & 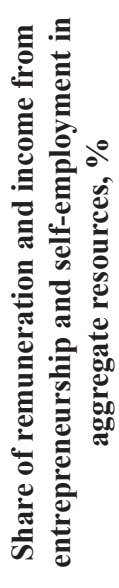 & 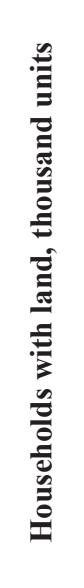 & 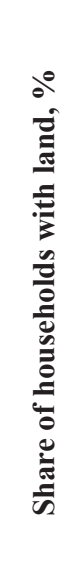 & 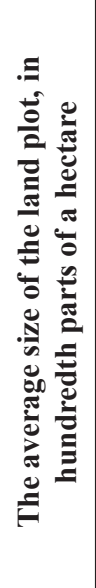 & 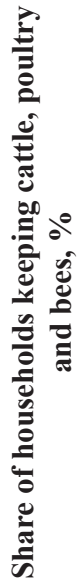 \\
\hline $\begin{array}{l}\text { Share of } \\
\text { households } \\
\text { keeping cattle, } \\
\text { poultry and } \\
\text { bees, \% }\end{array}$ & 0,07 & 0,22 & $-0,22$ & 0,40 & $-0,04$ & $-0,08$ & $-0,53$ & 0,21 & 0,44 & $-0,03$ & 1,00 \\
\hline \multicolumn{12}{|c|}{ Distribution of land by type of household use, $\%$, including: } \\
\hline $\begin{array}{l}\text { for the grow of } \\
\text { produce only } \\
\text { for their own } \\
\text { needs }\end{array}$ & 0,54 & 0,09 & $-0,70$ & 0,90 & $-0,86$ & $-0,33$ & $-0,25$ & 0,66 & 0,78 & $-0,96$ & 0,13 \\
\hline $\begin{array}{l}\text { for the grow } \\
\text { of produce for } \\
\text { own needs and } \\
\text { for sale }\end{array}$ & 0,38 & 0,16 & $-0,15$ & $-0,04$ & $-0,23$ & 0,30 & $-0,24$ & 0,39 & 0,33 & 0,16 & 0,06 \\
\hline leased out & $-0,68$ & $-0,19$ & 0,58 & $-0,57$ & 0,75 & $-0,03$ & 0,38 & $-0,76$ & $-0,79$ & 0,49 & $-0,15$ \\
\hline for leisure only & 0,39 & 0,36 & $-0,64$ & 1,00 & $-0,72$ & $-0,46$ & $-0,25$ & 0,57 & 0,82 & $-0,81$ & 0,40 \\
\hline $\begin{array}{l}\text { just started to } \\
\text { master }\end{array}$ & 0,40 & 0,01 & $-0,31$ & 0,69 & $-0,45$ & $-0,18$ & $-0,41$ & 0,52 & 0,65 & $-0,55$ & 0,40 \\
\hline
\end{tabular}

Source: calculated by data (SSSU) and data from http://www.ukrstat.gov.ua/

The share of food expenditure in household's expenditure is insignificant, although inversely related to the prevalence of households $(-0.11)$. Such a somewhat unexpected result can be explained by the fact that lower income and, consequently, a higher share of food costs are typical for households where there are no workers (retired), and with the increase in the number of such farms, the share of subsidiaries decreases significantly $(-0.71)$. At the same time, an indirect inverse relationship exists between the share of active income in total household resources and the number and prevalence of households (-0.51 and -0.58 , respectively). Consequently, as other income opportunities expand, the propensity to farming in urban areas is reduced.

Regarding the average size of the land, it should be noted that it increases as the households prevalence decreases $(-0.76$, which is logical, since it is caused by limited http://ea.bg.ac.rs 
land resources). In 2008, the average size of the land was 21.1 hundredth parts of a hectare, and in 2018 - 46.9. The majority of the land is leased out (-0.79). The larger the size of the land plot, the smaller the amount allocated for growing produce for its own needs (-0.96). Similarly, in the absence of workers and with increasing economic burden, less and less of the area is allocated for food self-sufficiency $(-0.7$ and -0.86 , respectively). With the increase in the number of working members of the farm, the land is mainly used for self-sufficiency in food (0.9) and leisure activity (1.0). As the share of active income in total household resources increases, the share of leased out land increases $(0.38)$. The prevalence of cattle and poultry holdings is decreasing as the average number of employees per household decreases $(0.4)$ and the share of active income in total household resources increases $(-0.53)$.

Therefore, in urban households, households (owning a land plot) are not a form of food self-sufficiency in a difficult economic situation. This conclusion can be drawn from the fact that an increase in the economic burden, an increase in the share of households without any single worker, and an increase in the share of food costs in expenses leads to the decreasing propensity to maintain subsistence households (as in the number of households, and the allocation of land plots to provide for their own food needs). At the same time, it is confirmed by the thesis (Fredriksson et al., 2016) that with the increase of other incomes (in other spheres) the propensity to do subsistence farming decreases. It should also be noted that for urban territories (households with land plots), a typical trend is an increase in the average size of a land plot with the leasing out of an increasing part of it. At the same time, urban households are not indicative of the transformation of subsistence farming into market-oriented forms. That is due to the traditions of semi-subsistence farming in urban settlements with the aim, first of all, to satisfy their own needs for food and leisure, and on the other hand - because of the small size of land plots. So let us further explore what factors are important in terms of facilitating the market transformation of subsistence farms in rural areas (Table 4). 
Table 4. Results of the correlation analysis of the relationship between subsistence households in rural settlements with socio-economic conditions for rural settlements development, 2008-2018

\begin{tabular}{|c|c|c|c|c|c|c|c|c|c|c|c|}
\hline Indicator & 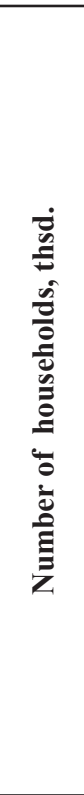 & 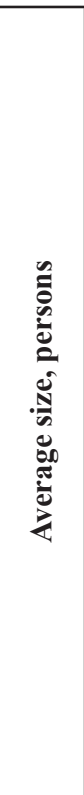 & 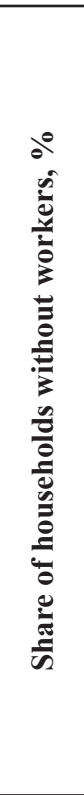 & 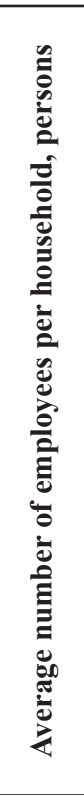 & 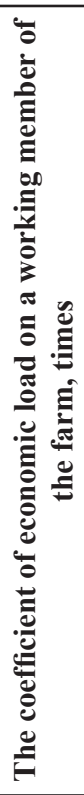 & 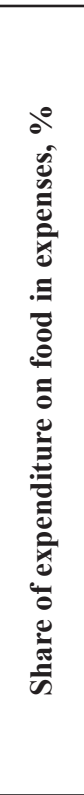 & 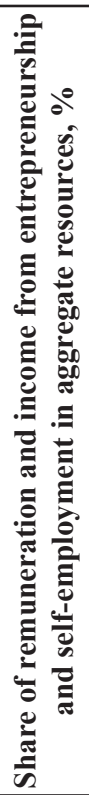 & 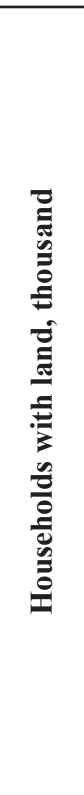 & 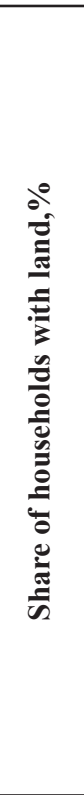 & 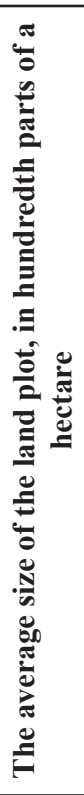 & 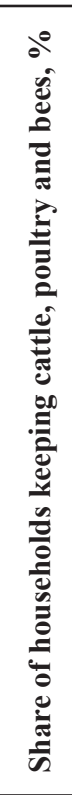 \\
\hline $\begin{array}{l}\text { PPH having land } \\
\text { plots, thousand }\end{array}$ & 1,00 & 0,90 & 0,64 & $-0,35$ & 0,60 & 0,53 & $-0,54$ & 1,00 & 0,47 & 0,19 & 0,62 \\
\hline $\begin{array}{l}\text { Share of } \\
\text { households with } \\
\text { land, \% }\end{array}$ & 0,38 & 0,56 & 0,28 & $-0,44$ & 0,33 & $-0,24$ & $-0,13$ & 0,47 & 1,00 & 0,62 & 0,67 \\
\hline $\begin{array}{l}\text { The average size } \\
\text { of the land plot, } \\
\text { in hundredth } \\
\text { parts of a hectare }\end{array}$ & 0,13 & 0,26 & 0,39 & $-0,48$ & 0,51 & $-0,41$ & $-0,01$ & 0,19 & 0,62 & 1,00 & 0,55 \\
\hline $\begin{array}{l}\text { Share of } \\
\text { households } \\
\text { keeping cattle, } \\
\text { poultry and } \\
\text { bees, \% }\end{array}$ & 0,58 & 0,67 & 0,71 & $-0,66$ & 0,63 & 0,17 & $-0,54$ & 0,62 & 0,67 & 0,55 & 1,00 \\
\hline \multicolumn{12}{|c|}{ Distribution of land area by type of household use, $\%$} \\
\hline $\begin{array}{l}\text { for the grow of } \\
\text { produce only for } \\
\text { their own needs }\end{array}$ & $-0,87$ & $-0,77$ & $-0,59$ & 0,41 & $-0,67$ & $-0,37$ & 0,45 & $-0,88$ & $-0,49$ & $-0,52$ & $-0,61$ \\
\hline $\begin{array}{l}\text { for the grow of } \\
\text { produce for own } \\
\text { needs and for } \\
\text { sale }\end{array}$ & 0,68 & 0,66 & 0,64 & $-0,56$ & 0,74 & 0,45 & $-0,69$ & 0,69 & 0,41 & 0,55 & 0,69 \\
\hline leased out & $-0,29$ & $-0,31$ & $-0,59$ & 0,63 & $-0,70$ & $-0,36$ & 0,70 & $-0,29$ & $-0,17$ & $-0,49$ & $-0,53$ \\
\hline $\begin{array}{l}\text { just started to } \\
\text { master }\end{array}$ & $-0,11$ & $-0,26$ & 0,43 & $-0,41$ & 0,51 & $-0,11$ & 0,00 & $-0,12$ & $-0,19$ & 0,30 & $-0,15$ \\
\hline
\end{tabular}

Source: calculated by data (SSSU) and data from http://www.ukrstat.gov.ua/ 
Thus, as evidenced by the results of the calculations (Table 4) and the available statistics (Table 2), the overall tendency to reduce the number of households in rural areas with land plots is closely and positively correlated with a decrease in the average household size $(0,9)$, a decrease in the proportion of households without employed persons (0.64) and a reduction in the economic burden per worker employed in the household (0.6). Also, the decrease in the share of expenditures on food in household expenditures is slightly but positively correlated with the number of holdings that have land (0.53). An increase in the share of active income in total household resources is also associated with a decrease in the number of land-owned households. But the greatest impact on their number has a decrease in the total number of rural households (1.0), i.e. depopulation of rural areas. Therefore, let us examine the influence of factors on the prevalence of such households.

With the increase in the average number of employees, the share of households having land plots declines on average (-0.44). The average size of the land plot is positively, although not strongly related to the share of households with land plots (0.62), and is lower, the greater the number of people working on the farm (-0.48), and more share of expenditures on food in expenses of the household (-0.41). Also, the average land size is positively and moderately related to the factor of the economic load: the smaller it is, the smaller the land size (0.51).

The prevalence of such phenomenon as the animal farm is closely and positively correlated with the average household size (0.67) and the share of households without employed persons (0.71), whereas with the increase in the average number of employees there is a tendency to livestock farming decreases $(-0.66)$. The same is true for increasing the share of active income in total household resources $(-0.54)$. As the economic burden decreases, the prevalence of animal husbandry also decreases (0.63).

An important feature of a household is how it uses land. As the average size of the household decreases, the share of the area used to support its food needs increases $(-0.77)$. This is also true for the number of households without employed persons $(-0.59)$ and the coefficient of economic burden $(-0.67)$. With the decrease in the share of food expenditures (which can be construed as a rise in cash income), households use the land more to cover their own food needs (-0.37) and lease it out (-0.36). Also close and positive is the relationship between the factor of economic load and the more use of land for growing products, including for sale (0.74). The average number of employees positively but moderately correlates with the renting out of the land (0.63), the provision of their own food needs (0.41), but inversely - with its use for growing products, including for sale (-0.56). So, let us emphasize based on abovementioned that the commercialization of households is closely associated:

- With the proportion of households without workers - the smaller this share is, the less market-oriented the farms are (0.64);

- With the coefficient of economic load - the higher it is, the more marketoriented is the market activity of the households (0.74); 
- With the share of food expenditure in all expenditures - the higher it is, the more market-oriented the household is $(0.45)$;

- With an average number of employees in the farm - the higher it is, the less market-driven the farm (-0.56);

- With the share of active income in aggregate resources (the higher it is, the less market-active is the household -0.69).

So, farms that use the land to a greater extent for growing produce for their use and sale are non-working households. In the event of a socio-economic recovery when greater employment opportunities arise, those households redirect their resources to support their own food needs and rent the land out.

Finally, let us examine how the socio-economic factors of regional development affect the activities and development of personal peasant households - a certain legal form of agricultural activity by households, which comes closest to the market-oriented form of activities (Table 5). While the households are more hobbies, the PPHs are a lifestyle, a form of societal existence, as it not only provides for basic needs but also - a selfemployed job.

Table 5. Results of the correlation analysis of the relationship between the characteristics of maintaining PPHs with the socio-economic conditions of regional development, 2018

\begin{tabular}{|c|c|c|c|c|c|c|}
\hline Indicator & 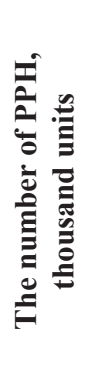 & 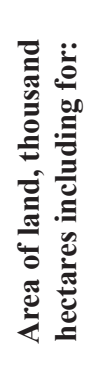 & 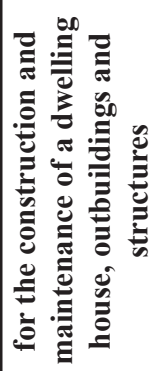 & 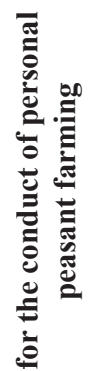 & 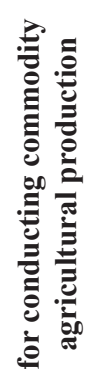 & 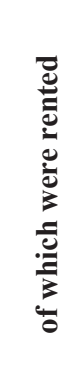 \\
\hline $\begin{array}{l}\text { Number of households located in urban } \\
\text { settlements, thousand units }\end{array}$ & $-0,14$ & 0,43 & $-0,11$ & $-0,18$ & 0,57 & 0,66 \\
\hline $\begin{array}{l}\text { Number of households located in rural } \\
\text { settlements, thousand units }\end{array}$ & 0,89 & 0,27 & 0,86 & 0,46 & $-0,11$ & $-0,24$ \\
\hline $\begin{array}{l}\text { Share of households located in rural } \\
\text { settlements, \% }\end{array}$ & 0,59 & $-0,28$ & 0,54 & 0,39 & $-0,61$ & $-0,74$ \\
\hline Average household size, persons & 0,50 & 0,04 & 0,44 & 0,42 & $-0,27$ & $-0,46$ \\
\hline $\begin{array}{l}\text { Number of households with land, thousand } \\
\text { units }\end{array}$ & 0,29 & 0,29 & 0,32 & 0,00 & 0,26 & 0,31 \\
\hline $\begin{array}{l}\text { Number of households keeping cattle, } \\
\text { poultry and bees, thousand units }\end{array}$ & 0,84 & 0,08 & 0,79 & 0,53 & $-0,33$ & $-0,46$ \\
\hline $\begin{array}{l}\text { Number of households without a single } \\
\text { worker, thousand units }\end{array}$ & $-0,09$ & 0,37 & $-0,01$ & $-0,11$ & 0,46 & 0,56 \\
\hline $\begin{array}{l}\text { Average number of employees per } \\
\text { households, persons }\end{array}$ & 0,55 & 0,03 & 0,39 & 0,08 & $-0,11$ & $-0,18$ \\
\hline
\end{tabular}




\begin{tabular}{|c|c|c|c|c|c|c|}
\hline Indicator & 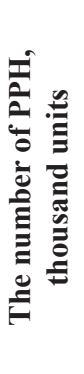 & 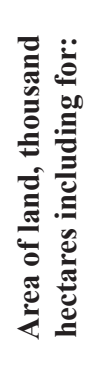 & 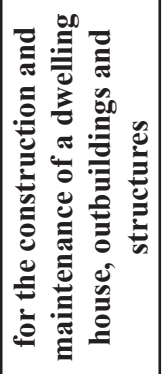 & 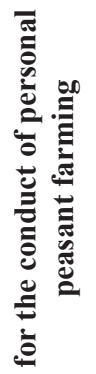 & 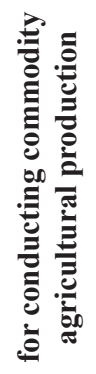 & 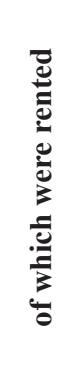 \\
\hline $\begin{array}{l}\text { The coefficient of economic load per } \\
\text { worker, times }\end{array}$ & $-0,20$ & $-0,01$ & $-0,04$ & 0,38 & $-0,19$ & $-0,29$ \\
\hline $\begin{array}{l}\text { The level of economic activity at the age of } \\
15-70 \text { years, } \%\end{array}$ & $-0,28$ & $-0,16$ & $-0,29$ & $-0,62$ & 0,21 & 0,28 \\
\hline $\begin{array}{l}\text { Unemployment rate as a percentage of } \\
\text { economically active population of } 15-70 \\
\text { years, } \%\end{array}$ & $-0,54$ & $-0,32$ & $-0,48$ & $-0,22$ & $-0,12$ & $-0,03$ \\
\hline $\begin{array}{l}\text { Percentage of informally employed } \\
\text { population to employed population, \% }\end{array}$ & 0,01 & $-0,14$ & 0,05 & 0,03 & $-0,18$ & $-0,34$ \\
\hline
\end{tabular}

Source: calculated by data (SSSU) and data from http://www.ukrstat.gov.ua/

The number of PPHs is closely related to the number of rural households in the regions (0.89). Although, this is not the case for PPHs land: as the share of rural households increases, the total area of farmland is reduced (-0.28), that is, with the increase in their number and share, the size decreases. The number of PPHs will be higher in those regions where the average farm size is larger (0.5) (which is typical for rural areas). PPHs are mainly livestock and poultry households $(0.84)$. They are rather developed in regions where the average number of employees on one farm is higher (0.55). It is interesting that as the unemployment rate increases, the number of PPHs will decline, meaning that this activity is not perceived as a proper alternative to a full day engagement (-0.54), but rather as a part-time employment. In regions where the number of households without a single worker is higher, the total area occupied by PPHs will be higher (0.37), this is also true in the case of urban households (0.43). At the same time, the area of $\mathrm{PPH}$ is more directed to commodity production with increasing level of urbanization, as well as with the increase in the number of households where there are no workers (0.46). In this case, these areas are formed through rented land (0.66 and 0.56 , respectively). The number of PPHs, as noted above, correlates with the number of livestock, poultry and bee holdings (0.84). Moreover, with the increase in the number of such farms, PPH areas are allocated for the maintenance of a dwelling house (0.79) and conduct of personal peasant farming $(0.53)$ but are eliminated from commodity production $(-0.33)$ and rental relations $(-0.46)$.

\section{Conclusions}

To sum up, we would like to emphasize that nowadays there is a decrease in the number of households involved in agricultural production both for food self-sufficiency and 
for the production of products for sale in Ukraine. And there is not only an absolute reduction in the number of such farms but a reduction in their share in the total number of households, that is, the prevalence of this phenomenon. There are "subsistence" structural shifts in the sector, highlighted by Buchenrieder et al. (2009). At the same time, it is necessary to pay attention to the nature of these structural changes: the gradual disappearance of individualized agricultural production with the allocation of agricultural land for use by large agricultural producers. This poses a threat to the effective development of rural areas and the agricultural sector, as individual forms of farming are seen as the basis for the development of efficient agriculture in a market economy, in particular in European countries (Lerman, Csaki and Feder, 2002), and the emergence of such an economic model in Ukraine, was the main goal of the land reform started almost 20 years. Therefore, in the context of the need to tackle the problem of semi-subsistence farming, one should pay attention to another aspect of this problem - the lack of a strategy to support the establishment of a model of individual farming, which must counteract the risks of industrialized agro-production. After all, as the results of the analysis show, in the case of a revival of economic activity in rural areas (peripheral territories) as a result of the implementation of social policy measures, there will be a disappearance of the class of private small agricultural producers. This poses risks to food security, as it is these structures that make up the bulk of consumer basket products. So we should not throw out the baby along with the bath, to wit commercializing it to the point where there are only big-scale holdings left and strive to balance interests of big players with those of smaller producers and societal needs.

At the same time, the results of the conducted research give grounds to single out the general problems of domination of semi-subsistence economy in Ukraine and tendencies of development of such farms under different socio-economic conditions. We found that the commercialization of households is closely associated: 1) With the proportion of households without workers - the smaller this share is, the less marketoriented the farms are; 2) With a coefficient of economic burden - the higher it is, the more market-oriented is the market activity of the households; 3) With the share of food expenditure in all expenditures - the higher it is, the more market-oriented the household is; 4) With an average number of workers in the farm - the higher it is, the less market-driven the farm; 5) With the share of active income in aggregate resources - the higher it is, the less market-active is the household.

Factors that we have identified as those leading to the spread of the semi-subsistence farming should be matched by incentives mechanism in relevant government programs. On the governance level an understanding must come that the spread of SSF is unattainable in the long run, so irrespective of any now-days rationales growing demand for food, low efficiency of SSF and 'isolation' (in terms of taxes paid to community treasure) from local community needs determine palpable necessity to confront the spread of SSF with countermeasures on a policy level.

Out of this dichotomy 'commercialization or deeper self-sufficiency' as there couldn't be two victors, commercialization appears as a way forward for SSF. It is corroborated http://ea.bg.ac.rs 
by EU experience and the predicted future trends in society and agriculture. Although it must be wise and moderate commercialization which leaves the room for striving individuals farms so vital for agriculture.

An interesting possibility for further research that would complement the analysis pursued in the paper would be, to develop policy measures aimed at promoting the development of private farms from an existing number of market-oriented households, to conduct more indepth qualitative studies needed to identify the rationale, motives and factors that determine the inclination of people of a particular age, in a particular locality to single out the path either of semi-subsistence farming or the commercialization of farm production activities.

\section{Conflict of interests}

The authors declare no conflict of interest.

\section{References}

1. AGRICULTURE OF UKRAINE 2009-2018. Сільське господарство України: статистичний збірник (за 2009-2018 pp.). [in English: Agriculture of Ukraine: statistical collection (for 2009-2018). The State Statistics Service of Ukraine]. http://www.ukrstat.gov.ua

2. Alexandri, C., Luca, L. \& Kevorchian, C. (2015). Subsistence Economy and Food Security - The Case of Rural Households from Romania. Procedia Economics and Finance, 22, 672-680. doi: 10.1016/S2212-5671(15)00282-8

3. Buchenrieder, G., Fritzsch, J., Wegener, S., Curtiss, J., \& Gomez y Paloma, S., (2009). Semi-subsistence farm households and the non-farm rural economy Perspectives and challenges. 111th Seminar, June 26-27, 2009, Canterbury, UK 52804, European Association of Agricultural Economists. https://www.researchgate. net/publication/46472310

4. COUNCIL REGULATION. (2005). (EC) No 1698/2005 of 20 September 2005 on support for rural development by the European Agricultural Fund for Rural Development (EAFRD). Available at: http://data.europa.eu/eli/reg/2005/1698/201112-21 (Accessed: November 2019).

5. Csata,A. (2018). Analysis of Accessing Rural DevelopmentFunds. Acta Universitatis Sapientiae, Economics and Business, 6(1), 113-134. doi: 10.1515/eb-2018-0006.

6. Davidova, S. (2011). Semi-Subsistence Farming: An Elusive Concept Posing Thorny Policy Questions. Journal of Agricultural Economics, 62(3), 503-524. doi: 10.1111/j.1477-9552.2011.00313.x.

7. Davidova, S. (2014). Small and Semi-subsistence Farms in the EU: Significance and Development Paths. EuroChoices, 13(1), 5-9. doi: 10.1111/1746-692X.12043.

8. EUROPEAN PARLIAMENT. (2013). Semi-subsistence farming: value and directions of development. https://www.europarl.europa.eu/RegData/etudes/etudes/ join/2013/495861/IPOL-AGRI_ET(2013)495861_EN.pdf 
9. FAO (2009). Report of the fao expert meeting on how to feed the world in 2050. Available at: http://www.fao.org/fileadmin/templates/wsfs/docs/EM_report/EM_ report.pdf

10.Forgács, C. (2012). Semi-subsistence farming situation and policy - the example of Hungary. Applied Studies In Agribusiness And Commerce, 6(1-2), 143-148. doi: 10.19041/Apstract/2012/1-2/20.

11. Fredriksson L., Bailey A., Davidova S., Gorton M. \& Traikova D. (2016). Pathways to Commercialisation of Semi-Subsistence Farms: Lessons Learnt from Rural Transformation in Central and Eastern European Countries. The Food and Agriculture Organization (FAO) of the United Nations. http://www.fao.org/3/abp145e.pdf

12.Fritzsch J., Wegener S., Buchenrieder G., Curtiss J., Gomez Y Paloma S., \& Burrell A. (2010). Economic Prospects for Semi-subsistence Farm Households in EU New Member States. The European Commission's science and knowledge service. http:// publications.jrc.ec.europa.eu/repository/bitstream/JRC58621/jrc58621.pdf

13. Giurca, D. (2008). Semi-Subsistence Farming - Prospects for the Small Romanian Farmer to Choose between a "Way of Living" or Efficiency". Agricultural Economics and Rural Development, Institute of Agricultural Economics, vol. 5(3-4), 215-230, ftp://www.ipe.ro/RePEc/iag/iag_pdf/AERD0804_215-230.pdf

14.Jędrzejczak-Gas, J. (2018). Self-employment as a Form of Entrepreneurship Development in Rural Areas in Poland. in International Scientific Days 2018. Towards Productive, Sustainable and Resilient Global Agriculture and Food Systems: Proceedings. Wolters Kluwer ČR, Prague, p. 1191. doi: 10.15414/isd2018. s5.03.

15.LAW OF UKRAINE (2003). Про особисте селянське господарство : Закон України від 15.05.2003 № 742-IV. Верховна Рада України. [in English: Law of Ukraine On Personal Peasant Farm from 15 th of May 2003 year \# 742-IV]. http:// zakon.rada.gov.ua/go/742-15.

16.Lerman, Z., Csaki, C. \& Feder, G. (2002). Land Policies and Evolving Farm Structures in Transition Countries. The World Bank (Policy Research Working Papers). doi: 10.1596/1813-9450-2794.

17.Lerman, Zvi. (2012). Land reform and farm performance in Europe and Central Asia: a 20 year perspective. Discussion Papers 120260, Hebrew University of Jerusalem, Department of Agricultural Economics and Management.

18.Popescu, D.-L. (2014). Subsistence/Semi-subsistence Agricultural Exploitations: Their Roles and Dynamics within Rural Economy/Rural Sustainable Development in Romania. Procedia Economics and Finance, 16, 563-567. doi: 10.1016/S22125671(14)00840-5.

19.Rickard, S. (2015). Food Security and Climate Change: The Role of Sustainable Intensification, the Importance of Scale and the CAP. EuroChoices, 14(1), 48-53. doi: 10.1111/1746-692X.12082. 
20.SSSU «Соціально-демографічні характеристики домогосподарств України»: Статистичний збірник (2009-2018 pp.) [in English: Social and Demographic Characteristics of Households of Ukraine: statistical collection (2009-2018). The State Statistics Service of Ukraine]. http:/www.ukrstat.gov.ua/druk/publicat/ Arhiv_u/17/Arch_cdhd_zb.htm.

21.SSSU (2015). Про затвердження Методологічних положень 3 організації державних статистичних спостережень зі статистики рослинництва Держстат України; Наказ від 28.12.2015 № 370 [in English: decree of The State Statistics Service of Ukraine "On Approval of Methodological Provisions on the Organization of State Statistical Surveys on Crop Statistics"]. https://zakon.rada. gov.ua/rada/show/v0370832-15/print

22.SSSU (2018). Основні сільськогосподарські характеристики домогосподарств у сільській місцевості в 2018 році. [in English: The main agricultural characteristics of rural households in 2018. The State Statistics Service of Ukraine]. http:/www. ukrstat.gov.ua/

23.STATISTICAL YEARBOOK OF UKRAINE 2009-2018 Статистичний щорічник України (за 2009-2017 pp.). [in English: Statistical Yearbook of Ukraine (20092018). The State Statistics Service of Ukraine]. http:/www.ukrstat.gov.ua

24. Strochenko, N., Koblianska I., \& Markova, O. (2017). Structural Transformations in Agriculture as Necessary Condition for Sustainable Rural Development in Ukraine. Journal of Advanced Research in Law and Economics, Volume VIII, Spring, 1(23), 237 - 249. DOI: 10.14505/jarle.v8.1(23).27.

25.Строченко H.I., Коблянська I.I. (2016) Сутнісно-організаційні трансформації господарювання на селі як основа сталого сільського розвитку в Україні. Маркетинг і менеджмент інноващій, № 3, 293-308. [in English: Strochenko, N.I., \& Koblianska, I.I. (2016). Essential and Organizational Transformations of Economy Management in the Countryside as the Basis of Sustainable Rural Development in Ukraine. Marketing and management of innovations, Vol.3, 293308. http://essuir.sumdu.edu.ua/bitstream/123456789/46502/1/Strochenko\%2c\%20 Koblianska.pdf]

26.Свиноус, I. В. (2009). Теоретико-методологічні проблеми ототожнювання понять «особисте селянське господарство» та «суб'єкт підприємницької діяльності». Актуальні проблеми розвитку економіки регіону, 5 (2), 158-163. [in English: Svynous, I. V. (2009). Theoretical and methodological problems equate the concepts of «personal peasant economy» and «business entity». Actual problems of the region's economy, 5 (2), 158-163].

27.WORLD BANK. (2016) Structural Transformation of Moldovan Smallholder Agriculture: Implications for Poverty and Shared Prosperity. Moldova Poverty Assessment 2016. Report No. 105724-MD. http://documents.worldbank.org/ curated/en/847331468184784843/pdf/105724-WP-P151472-PUBLIC-STUDIUII-BM-en-COR-final.pdf 